\title{
Microbial diversity of bioaerosol inside sports facilities and antibiotic resistance of isolated Staphylococcus spp.
}

\author{
Marta Małecka-Adamowicz (i) - Lukasz Kubera • Emilia Jankowiak • \\ Ewa Dembowska
}

Received: 20 December 2018/ Accepted: 12 October 2019/Published online: 21 October 2019

(C) The Author(s) 2019

\begin{abstract}
In the modern world, healthy habits and physical and mental fitness are more important than ever. A growing number of people participate in sports to improve their overall health. However, the conditions in which people exercise are seldom examined. It is obvious that the air in buildings, including sports facilities, can be contaminated with pathogenic microorganisms, causing infections and allergies. Our study was aimed at assessing microbial air quality inside several sports facilities (fitness room, martial arts room, swimming pool, sports hall, gym) and at a sports field. Another objective was to evaluate the antibiotic resistance of isolated Staphylococcus strains. Air samples were collected with MAS-100 sampler, using selective substrates. Antibiotic resistance of mannitol-positive staphylococci was assessed using a disk diffusion method in accordance with EUCAST recommendations. The results indicated large fluctuations in average concentrations of heterotrophic bacteria, ranging from $38 \mathrm{CFU} \mathrm{m}{ }^{-3}$ (swim-

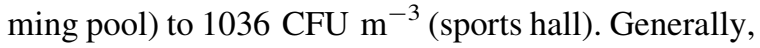
bacteria were more abundant inside the buildings, while fungi in the sports field $\left(658 \mathrm{CFU} \mathrm{m} \mathrm{m}^{-3}\right.$ on average). In all facilities, airborne fungal communities
\end{abstract}

M. Małecka-Adamowicz $(\bowtie) \cdot$ Ł. Kubera .

E. Jankowiak · E. Dembowska

Department of Microbiology and Immunobiology, Faculty of Biological Science, Kazimierz Wielki University, ul.

Al. Powstańców Wielkopolskich 10, 85-090 Bydgoszcz,

Poland

e-mail: marmal@ukw.edu.pl were dominated by the genus Cladosporium, followed by Penicillium, Fusarium and Acremonium. Alternaria and Aureobasidium constituted only a small percentage of isolated molds. We recorded only low concentrations of mannitol-positive staphylococci (on average ranging from $1 \mathrm{CFU} \mathrm{m}^{-3}$ at the swimming pool and sports field to $9 \mathrm{CFU} \mathrm{\textrm {m } ^ { - 3 }}$ in the martial arts room). Of all isolated Staphylococcus strains, 73\% were resistant to benzopenicillin, while more than $90 \%$ were sensitive to gentamycin, levofloxacin and rifampicin.

Keywords Bioaerosols - Sports facilities · Antimicrobial resistance - Air contamination . Staphylococcus spp. · Fungi

\section{Introduction}

Today, much emphasis is placed on keeping fit and active leisure. According to the World Health Organization adults need at least $150 \mathrm{~min}$ of moderate physical activity per week (WHO 2016). The benefits of regular exercise include improved physical and mental shape (Onchang and Panyakapo 2014). People who attend fitness centers feel happier and healthier and boast increased energy level. Moreover, habitual sports participation reduces the risk of chronic diseases and helps maintain good body weight (Ramos et al. 2015a). 
Nowdays, there is a wide range of sports facilities available, for example: gyms, swimming pools, fitness rooms and sports fields. Their characteristics depend on the size, function (pattern of use) and energy consumption (Revel and Arnesano 2014). Indoor air quality is determined not only by different types and sources of pollutants, but also by construction materials, building maintenance and ventilation. It also depends on types of activities and jobs performed inside (Ramos et al. 2014). A proper air change rate is vital in controlling microbial growth in interior spaces. Specific conditions in fitness centers such as high moisture due to intense sweat discharge of the users, resuspension of dust from the ground due to intense physical activities and regular contact between the users and surfaces (exercise instruments, floor mats, handrails) promote microbial growth (Ramos et al. 2015b). Airborne bacteria and fungi attached to fine particulate matter (PM2.5) significantly affect human health (Du et al. 2018). They may cause breathing problems, cough or even asthma attacks (Lu et al. 2009). Increased levels of microorganisms can be introduced into the respiratory system during physical activities, posing a considerable health risk. Since the air is generally inhaled through the mouth during exercise, and at a higher than normal rate, the intake of airborne contaminants increases, with increased penetration to the lower parts of lungs. Moreover, exercising in highly polluted environments, such as certain areas of congested cities with heavy traffic, may considerably increase exposure to microbial risk (Kunzli 2002; Braniš et al. 2009). In order to reduce negative health effects of physical activities, regular monitoring of indoor air quality in sports facilities is highly recommended (Andrade et al. 2017).

The study was aimed at evaluating microbial air quality in sports facilities at the Centre of Physical Culture and Sport at Kazimierz Wielki University in Bydgoszcz. Another objective was to assess antibiotic resistance of isolated strains of Staphylococcus spp.

\section{Materials and methods}

Microbial tests were conducted at several sports facilities at the Centre of Physical Culture and Sport at Kazimierz Wielki University in Bydgoszcz. This sports complex is located in the city centre with a relatively high traffic flow. It is used by university students (principally by students of the faculty of Physical Education, Health and Tourism) and students of the university high school.

\subsection{Sampling sites and sampling}

Sampling was conducted in the following dry months: May, June, September, October and November using the impaction method, with MAS-100 air sampler (Merck, Germany) at six sampling sites (Table 1).

The amount of 50-100 L of air (depending on the expected contamination level) was filtered in the sampler's chamber containing a Petri dish filled with a suitable nutrient medium. The assessment of microbial contamination was carried out using Merck MAS-100 air sampler with a turbofan. Air is aspirated through a metal perforated lid (400 holes of a $1 \mathrm{~mm}$ diameter). The radial fan, controlled by a flow sensor, regulates air flow. The air is impacted onto the surface of growth medium in a sterile Petri dish.

At all sampling sites, sampling was conducted in three parallel repeats. The air samples were transported to the laboratory, placed in a thermostat and incubated for a specific time at an appropriate temperature. After that grown colonies were counted. The results were corrected using the table of statistical corrections according to Feller (1950) and expressed as colony-forming units per cubic meter of air (CFU m ${ }^{-3}$ ).

\subsection{Microbial research}

The microbial research was aimed at determining the following: (1) the total number of heterotrophic bacteria, (2) the number of mannitol-positive Staphylococcus spp. and their antibiotic resistance (3) the number of molds and their identification.

The total number of heterotrophic bacteria was determined using trypticase soy lab agar medium (BTL, Poland). The bacteria were incubated at $37{ }^{\circ} \mathrm{C}$ for $48 \mathrm{~h}$, then grown colonies were counted, and their number was expressed as colony-forming units per cubic meter of air $\left(\mathrm{CFU} \mathrm{m} \mathrm{m}^{-3}\right)$.

The presence of mannitol-positive staphylococci was detected using Chapman's nutrient medium (BTL, Poland). Bacterial cultures were incubated at $37{ }^{\circ} \mathrm{C}$ for $48 \mathrm{~h}$, and then grown colonies were counted. Bright yellow zones around a grown colony indicated a positive result. Additionally, the strains were gram 
Table 1 Description of sampling sites

\begin{tabular}{|c|c|c|c|c|c|}
\hline Sampling sites & Location & Coordinates & Studied area $\left(\mathrm{m}^{2}\right)$ & $\begin{array}{l}\text { Volume } \\
\left(\mathrm{m}^{3}\right)\end{array}$ & $\begin{array}{l}\text { Average of } \\
\text { temperature }\left({ }^{\circ} \mathrm{C}\right)\end{array}$ \\
\hline $\mathrm{I}-\mathrm{gym}$ & $\begin{array}{l}\text { Building, second } \\
\text { floor }\end{array}$ & $\begin{array}{l}53^{\circ} 07^{\prime} 34.3^{\prime \prime} \mathrm{N} \\
18^{\circ} 01^{\prime} 34.8^{\prime \prime} \mathrm{E}\end{array}$ & 103.86 & 381.16 & 21 \\
\hline II-fitness room & $\begin{array}{l}\text { Building, second } \\
\text { floor }\end{array}$ & $\begin{array}{l}53^{\circ} 07^{\prime} 34.3^{\prime \prime} \mathrm{N} \\
18^{\circ} 01^{\prime} 34.8^{\prime \prime} \mathrm{E}\end{array}$ & 89.15 & 280.82 & 21 \\
\hline III-sports hall & $\begin{array}{l}\text { Building, ground } \\
\text { floor }\end{array}$ & $\begin{array}{l}53^{\circ} 07^{\prime} 34.3^{\prime \prime} \mathrm{N} \\
18^{\circ} 01^{\prime} 34.8^{\prime \prime} \mathrm{E}\end{array}$ & 1331.62 & 20,547 & 21 \\
\hline $\begin{array}{l}\text { IV_-martial arts } \\
\text { room }\end{array}$ & $\begin{array}{l}\text { Building, ground } \\
\text { floor }\end{array}$ & $\begin{array}{l}53^{\circ} 07^{\prime} 34.3^{\prime \prime} \mathrm{N} \\
18^{\circ} 01^{\prime} 34.8^{\prime \prime} \mathrm{E}\end{array}$ & 300 & 1800 & 21 \\
\hline $\begin{array}{l}\mathrm{V} \text {-swimming } \\
\text { pool }\end{array}$ & $\begin{array}{l}\text { Building, ground } \\
\text { floor }\end{array}$ & $\begin{array}{l}53^{\circ} 07^{\prime} 34.3^{\prime \prime} \mathrm{N} \\
18^{\circ} 01^{\prime} 37.6^{\prime \prime} \mathrm{E}\end{array}$ & 921.57 & 5000 & 28.2 \\
\hline VI-sports field & $\begin{array}{l}\text { Outdoor between } \\
\text { buildings }\end{array}$ & $\begin{array}{l}53^{\circ} 07^{\prime} 38.0^{\prime \prime} \mathrm{N} \\
18^{\circ} 01^{\prime} 37.1^{\prime \prime} \mathrm{E}\end{array}$ & $\begin{array}{l}8064 \text { including a safety } \\
\text { zone }\end{array}$ & & 17.6 \\
\hline
\end{tabular}

stained and identified under a microscope. Taxonomic analysis of the strains was performed using API tests (API Staph bioMerieux, France).

Antibiotic resistance of the identified Staphylococcus strains was determined using the disk diffusion method. Paper disks containing antibiotics were placed on Mueller-Hinton medium (BioMaxima, Poland) inoculated with randomly selected strains of mannitol-positive staphylococci. Eight different groups of antibiotics of specified concentration (penicillin-P 1 unit, cefoxitin-FOX $30 \mu \mathrm{g}$, gentamycin-CN $10 \mu \mathrm{g}$, erythromycin-E $15 \mu \mathrm{g}$, tetracycline-TE $30 \mu \mathrm{g}$, levofloxacin-LEV $5 \mu \mathrm{g}$ and rifampicin-RD $5 \mu \mathrm{g}$ ) were used to assess the full spectrum of resistance of the strains. After an 18-h incubation at $37{ }^{\circ} \mathrm{C}$ we measured zones of inhibited growth formed around the disks. The results were compared with the guidelines of the European Committee on Antimicrobial Susceptibility Testing (EUCAST 2015). Subsequently, the investigated strains were divided into three groups: susceptible, moderately susceptible and resistant to antibiotics.

The number of molds was determined using Sabouraud's nutrient medium (BTL, Poland). The microorganisms were incubated at $26{ }^{\circ} \mathrm{C}$ for 5 days, after which time grown colonies were counted and their number was expressed as colony-forming units per cubic meter of air $\left(\mathrm{CFU} \mathrm{m}{ }^{-3}\right)$. Molds were identified on the basis of their macro- and microscopic features using the key of Samson et al. (2000).
All media were prepared according to manufacturers' instructions.

Statistica 13 software was used for statistical analysis of the results. The inter-group differences were determined using the Kruskal-Wallis $\mathrm{H}$ test (one-way ANOVA). Post-hoc Tukey's test was used to determine intra-group differences. Pearson correlation coefficient was determined in order to analyze the relationship between the obtained values. Statistical tests were carried out at the significance level $p \leq 0.05$.

\section{Results and discussion}

\subsection{Polish norms and law}

Currently, there are no relevant standards defining acceptable levels of microbial air contamination in Poland. Standards PN-89/Z-04111/02 and PN-89/Z$04111 / 0$, withdrawn in 2015 , have not yet been replaced. As a result, air quality assessment is based on the limit values of microbial contamination defined in the old documents. Alternatively, the results are interpreted according to different guidelines from researchers and institutions (Chmiel et al. 2015). Relevant organizations should establish explicit criteria for evaluating indoor and outdoor air quality (Wolny-Koładka et al. 2019). 


\subsection{Physical parameter: temperature}

The indoor microbiome is a complex system that varies according to the activities being performed, human flow, ventilation systems and physical parameters, such as temperature and humidity (Ramos et al. 2015b).

In the investigated facilities, the temperature was maintained at $21^{\circ} \mathrm{C}$. The exceptions included the swimming pool (sampling site $\mathrm{V}$ ), where the temperature ranged from $26{ }^{\circ} \mathrm{C}$ (May) to $30{ }^{\circ} \mathrm{C}$ (September), with an average temperature of $28.2^{\circ} \mathrm{C}$, and sports field (sampling site VI), where the temperature was determined by weather conditions and ranged from $6{ }^{\circ} \mathrm{C}$ (November) to $29^{\circ} \mathrm{C}$ (June) with an average temperature of $17.6{ }^{\circ} \mathrm{C}$ (Table 1). All sites but the sports field had air-conditioning.

\subsection{Concentrations of bacterial bioaerosol}

All activities performed in sports facilities involve physical effort and intense perspiration, the latter leading to high humidity. Sports equipment also promotes the spread of bacterial cells. Our results showed large fluctuations in the concentrations of heterotrophic bacteria, i.e., from 6 to $2599 \mathrm{CFU} \mathrm{m}^{-3}$ (from 38 to $1036 \mathrm{CFU} \mathrm{m}^{-3}$ on average) (Table 2). Higher level of culturable bacterial aerosols were obtained by Brągoszewska et al. (2016) in classrooms (from 2500 to $3000 \mathrm{CFU} \mathrm{m}^{-3}$ ). Lower concentrations were noted by Ramos et al. (2015b) in fitness centers (824 CFU m ${ }^{-3}$ ) and by Goung et al. (2015) at indoor golf courses (383.1 CFU m $\mathrm{m}^{-3}$ ). Our results indicated also that the concentration of bacterial bioaerosol increased when the number of users was higher. This relationship could be observed at sampling site III (sports hall), where bacterial contamination was higher in October (the beginning of the academic year), i.e., $2599 \mathrm{CFU} \mathrm{m}^{-3}$ than in summer, i.e. $62 \mathrm{CFU} \mathrm{m}^{-3}$ (Table 2). At the same time, considerably lower concentrations of bacteria were recorded at sampling sites I (gym) and II (fitness room), empty throughout the year. It can therefore be concluded that the presence and movement of a large number of people in the room significantly affected bacterial contamination.

Literature reports also suggest that bacterial concentration is higher in the indoor air compared to the outdoor air (Meadow et al. 2014; Ramos et al. 2015b; Brągoszewska et al. 2016; Madureira et al. 2018; Brągoszewska et al. 2018).

Our study seemed to confirm the above observations. Airborne bacteria were generally more abundant in indoor sports facilities than in the sports field (sampling site VI) (Table 2).

\subsection{Concentrations of fungal bioaerosol}

Concentration of molds in the air depends largely on local conditions. Outside, crucial factors include landform and land use, weather conditions and plant diseases. Inside, it is influenced by outdoor air, ventilation, building materials and building maintenance, occupants and visitors, and mold infestation (Womack et al. 2010; Bowers et al. 2012; Madureira et al. 2018). In indoor, environment fungal bioaerosol contains molds from both indoor and outdoor sources (Hyvärinen et al. 2001).

The wind, street layout, presence or lack of trees and other landscaping plants may affect fungal growth and spread. In open spaces, where air movement contributes substantially to the dispersal of fungal spores, the concentrations of these microorganisms are higher than those indoors (Ejdys 2009). Concentrations of filamentous fungi were lower at sampling sites located inside the buildings (21-92 CFU m ${ }^{-3}$ on
Table 2 Number of heterotrophic bacteria in air (CFU m ${ }^{-3}$ )

$M$ mean, $S D$ standard deviation

\begin{tabular}{lrrrrrr}
\hline Sampling sites & \multicolumn{3}{c}{ Month of sampling } & \multirow{2}{*}{$M \pm$ SD } \\
\cline { 2 - 6 } & May & June & September & October & November & \\
\hline I-gym & 30 & 54 & 213 & 176 & 30 & $101 \pm 87$ \\
II-fitness room & 54 & 47 & 61 & 72 & 57 & $58 \pm 9$ \\
III-sports hall & 1850 & 62 & 149 & 2599 & 520 & $1036 \pm 1130$ \\
IV-martial arts room & 2460 & 300 & 53 & 303 & 300 & $683 \pm 999$ \\
V-swimming pool & 54 & 20 & 25 & 71 & 20 & $38 \pm 23$ \\
VI-sports field & 106 & 65 & 44 & 78 & 6 & $60 \pm 38$ \\
\hline
\end{tabular}


average) than those in the sports field ( $658 \mathrm{CFU} \mathrm{m}^{-3}$ ) (Table 3). Similar results were obtained by Frankel et al. (2012) who noted much lower concentrations of molds in the residential houses than those in their surroundings. Research by Rocha et al. (2017) also confirms high concentrations of molds in the atmospheric air (from 116.2 to $815 \mathrm{CFU} \mathrm{m}^{-3}$ ) in areas designated for sports and recreation in Fortaleza-CE of Brazil. Madureira et al. (2015) recorded low concentrations of molds in investigated rooms. The ratio of indoor-to-outdoor fungal concentration $\mathrm{I} / \mathrm{O}$ was around 1 , which means that the outdoor air was one of the main sources of indoor fungal bioaerosol.

There are many scientific reports confirming the fact that culture techniques do not provide sufficient information on microbial concentration in the air. Viable microorganisms identified by these methods may represent only a small percentage of all microbes. This may lead to the underestimation of bacterial and fungal concentrations (Cabral 2010; Madureira et al. 2018). The method used in this study detects only culturable fungi. However, many fungal species, including plant pathogens, such as powdery mildews, rust fungi and smut fungi, are viable but not culturable. This observation was confirmed by Adams et al. (2013), who detected also many taxa with a clear outdoor origin: plant pathogens, lichenized fungi, mushrooms and puffballs, in addition to fungi expected indoors (saprotrophic Dothideomycete and Wallemiomycete molds).

\subsection{Statistical analysis}

Statistical analysis based on the Kruskal-Wallis H test (one-way ANOVA) showed significant differences in the concentrations of heterotrophic bacteria and molds between sampling sites. On the other hand, the date of sampling did not significantly affect the results. The post-hoc tests were used to demonstrate an intra-group difference between the concentrations of heterotrophic bacteria at sampling site II (fitness room) and sampling site IV (martial arts room) $(p<0.05)$. For molds significant differences were noted between sampling site I (gym) and sampling site VI (sports field) $(p<0.01)$. Statistical analysis did not show any correlation between the concentrations of investigated microbial groups, volume of the facilities as well as air temperature.

\subsection{Predominant genera of airborne fungi}

The species composition of airborne bioaerosol can provide additional information on air quality or fungal infection. Numerous literature reports have indicated that molds and their secondary metabolites have a toxic effect on humans and animals and may cause a number of allergy symptoms. Clinically, the most important allergens are produced by fungi belonging to the following genera: Alternaria, Aspergillus, Cladosporium, Mucor, Penicilium and Fusarium (Grajewski and Twarużek 2004; Crameri et al. 2014; Pusz et al. 2014). According to Kuna (2002) and Jahnz-Rożyk (2008) hypersensitivity pneumonitis (HP), an inflamation of the alveoli within the lung, may be triggered by molds Aspergillus fumigatus, Aspergillus clavatus, Aspergillus niger, Aspergillus umbrosus, Penicillium casei and Penicillium glabrum (Penicillium frequentans). Mytotoxin-producing molds of Aspergillus, Penicillium, Fusarium, Stachybotrys, Alternaria and Cladosporium genera pose the greatest threat to humans and animals (Nabrdalik and Latała 2003; Ejdys 2009).

Cladosporium species are among the most common airborne fungi all over the world, especially in the temperate zone (Almaguer et al. 2015; Khan et al. 2016; Antón et al. 2019). In healthy buildings with low
Table 3 Number of fungi in air $\left(\mathrm{CFU} \mathrm{m} \mathrm{m}^{-3}\right)$

$M$ mean, $S D$ standard deviation

\begin{tabular}{lrrrrrr}
\hline Sampling sites & \multicolumn{3}{l}{ Month of sampling } & \multirow{2}{*}{$M \pm$ SD } \\
\cline { 2 - 6 } & May & June & September & October & November & \\
\hline I-gym & 30 & 60 & 10 & 0 & 6 & $21 \pm 24$ \\
II-fitness room & 68 & 70 & 57 & 30 & 3 & $46 \pm 29$ \\
III-sports hall & 40 & 90 & 70 & 60 & 24 & $57 \pm 26$ \\
IV-martial arts room & 70 & 27 & 25 & 30 & 3 & $31 \pm 24$ \\
V-swimming pool & 350 & 27 & 16 & 10 & 57 & $92 \pm 145$ \\
VI-sports field & 660 & 1230 & 880 & 340 & 180 & $658 \pm 420$ \\
\hline
\end{tabular}


humidity there is no appreciable indoor fungal growth, and outdoor Cladosporium prevails (Cabral 2010). Our results also indicated the predominance of Cladosporium in the outdoor bioaerosol: at sampling site VI (sports field) they constituted $94 \%$ of the fungal population (Fig. 1). At sampling sites V (swimming pool) and IV (martial arts room) a high percentage of Cladosporium was also recorded: 100 and $72 \%$, respectively. At the remaining sites their contribution was considerably lower (approx. 30\%). Viegas et al. (2010) indicated the presence of a wide variety of molds in bioaerosol at swimming pools, with several dominant genera: Cladosporium (36.6\%), Penicillium (19\%), Aspergillus (10.2\%), and Mucor (7\%). With regard to the qualitative assessment of fungal bioaerosol, several species recorded at indoor swimming pools, including Aspergillus fumigatus, A. versicolor, Trichoderma, Penicillium, Phialophora, Fusarium and Ulocladium species, are regarded as humidity indicators. All pose a potential health risk. In addition, A. fumigatus is one of the most common airborne saprobiotic fungi, capable of causing severe or fatal aspergillosis (Yao and Mainelis 2007).

Along with Cladosporium, the air at sampling sites I (gym) and III (sports hall) contained molds of Fusarium and Acremonium genera (approx. 30\%) (Fig. 1). The air at sampling site II (fitness room) was also contaminated with fungi of the genus Penicillium (70\%). The predominance of Penicillium and Aspergillus often indicates fungal infestation in the building due to moisture problems or water demage. According to Cabral (2010) in sick buildings high humidity promotes fungal growth (mainly of Penicillium and Aspergillus) with accompanying release of conidia and cell fragments into the atmosphere. Penicillium exposure has been associated with asthma, while Aspergillus exposure, with atopy (Garrett et al. 1998).

Similarly, Kallawicha et al. (2019) observed that Aspergillus/Penicillium spores were the most abundant fungal spore taxa in the laboratories (40.6\%), followed by Cladosporium (30\%) and ascospores (17\%).

There is an abundance of reports of seasonal and diurnal patterns of airborne fungi both indoors and outdoors (Oliveira et al. 2009; Grinn-Gofroń 2011; Skjøth et al. 2016; Maya-Manzano et al. 2016; Bardei et al. 2017; Antón et al. 2019). Spore release depends not only on the type of fungi but also on weather conditions. The concentration of spores in the home environment increases with their increased concentration in the outdoor air. Some spores are released when the air is dry, and their concentration increases with strong wind and sunlight and reduced humidity, e.g., the spores of the Alternaria, Cladosporium or
Fig. 1 Predominant genera of airborne fungi at all sampling sites. I-gym, IIfitness room, III-sports hall, IV-martial arts room, $\mathrm{V}$-swimming pool, VIsports field

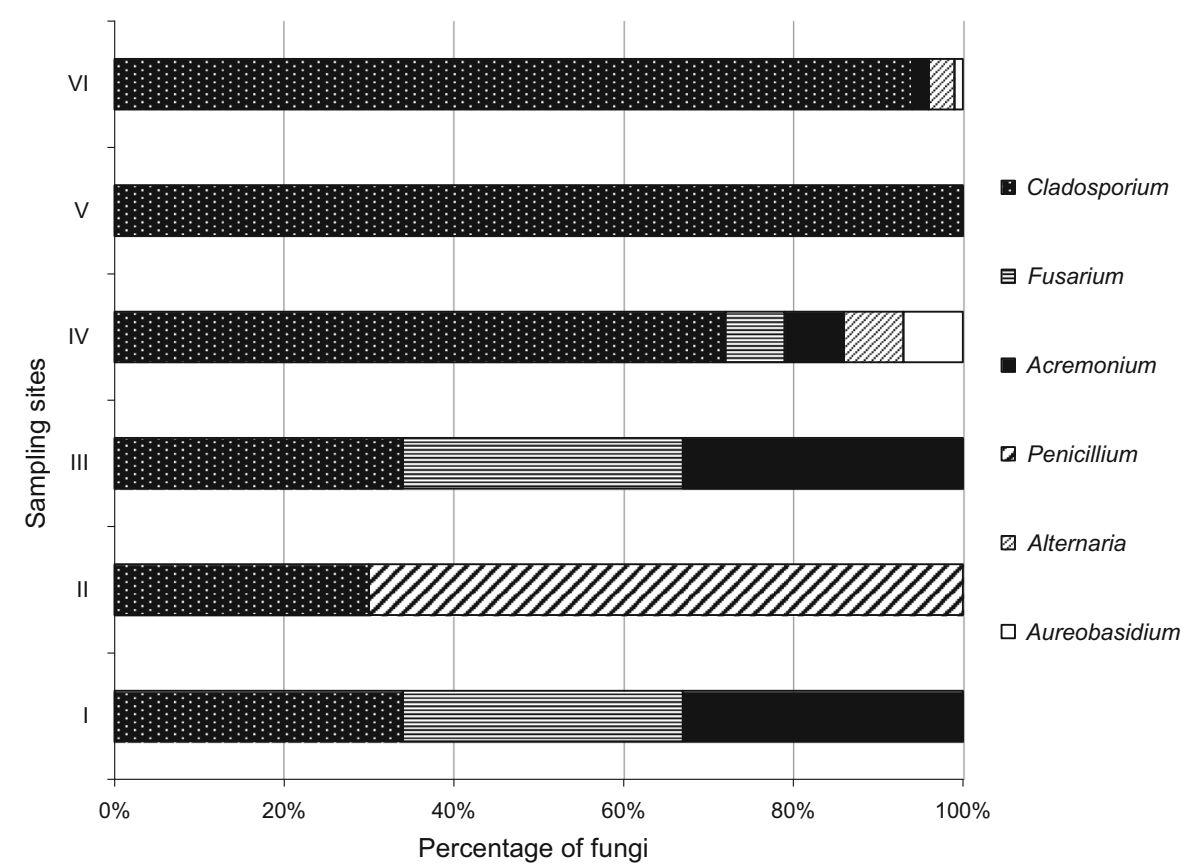


Helminthosporium genera. On the other hand, the spores produced by fungal species belonging to Ascomycota class are released into the atmosphere during rainfall, often at night (Platts-Mills et al. 1987). The results obtained by Antón et al. (2019) confirmed a division of spores into dry air spores (Alternaria, Aspergillus/Penicillium, Cladosporium and Periconia) and wet air spores (Agaricus, Coprinus and Leptosphaeria).

The same authors divided aeromycota into three categories, morning, afternoon and night spores, depending on their release pattern. Cladosporium and Leptosphaeria showed peaks between 2:00 and 4:00 in the morning, maintaining the stable spore concentration in the afternoon and decreasing at 22:00. Similarly, Sadyś (2017) noted maximum concentrations of Cladosporium at 9.00, while Das and GuptaBhattacharya (2012) assessing air quality in Kolkata (India) recorded the morning peak of Cladosporium and Alternaria at 11:00 and 12:00, respectively. Bardei et al. (2017) observed a uniform distribution of spores of Alternaria and Cladosporium during the day, with the peaks around 12:00-14:00 for Alternaria and 14:00-16:00 for Cladosporium. A number of studies have confirmed that the maximum concentrations of their spores are recorded late in the afternoon or in the evening, while the minimum, at night (Oliveira et al. 2009; Skjøth et al. 2016; MayaManzano et al. 2016). The total load of these fungal spores depends on the types of local sources and their dispersion (Bardei et al. 2017). Different data are provided by Ramos et al. (2015b), who noted night peaks of Cladosporium in fitness centres. According to the authors, the highest concentrations of other fungi, such as Penicillium sp., Chrysosporium sp., Acremonium sp., and Chrysonilia sp. were also recorded at night. In the morning, they noted the highest concentrations of Chrysosporium sp., Chrysonilia sp., Neoscytalidium hialinum, Sepedonium sp., and Penicillium sp. In addition, they identified toxigenic species (Aspergillus fumigatus, Aspergillus ustus), which are indicators of moisture and dampness in buildings. Some species of the genera Aspergillus, Eurotium, Chaetomium, Paecilomyces, Penicillium, Scopulariopsis, Stachybotrys, Trichoderma and Wallemia are used to detect high indoor humidity caused by water damage (Vesper et al. 2005).

The presence of Penicillium spores in the morning and at night/late in the evening has been confirmed by
Ramos et al. (2015b) and many other researchers. Grinn-Gofroń (2011) and Antón et al. (2019), examining the air in Szczecin (Poland) and Salamanca (Spain), respectively, recorded high concentrations of amerospores in the air late in the afternoon and early in the morning. In the studies in the United Kingdom, the number of these spores was highest at 11:00. (Millington and Corden 2005), while in Kolkata, at around 9:00 (morning peak) and at 16:00 (afternoon peak) (Das and Gupta-Bhattacharya 2012).

Researchers have observed that spores of many fungal species, including those of the genera Agaricus, Coprinus and Periconia (Antón et al. 2019), have a nocturnal release pattern. In the study of Das and Gupta-Bhattacharya (2012) some unidentified ascospores in the air of Kolkata displayed a nocturnal pattern with two peaks: at 23:00 and at 2:00. According to Elbert et al. (2007) and Lacey (1996) taxa that require high relative humidity, including many Basidiomycota, tend to release spores at night, when the humidity is the highest.

In the study by Antón et al. (2019), Cladosporium was irregularly distributed seasonally, with several peaks throughout the year, and with the highest concentration in summer and late autumn. Similar results were obtained in many cities in Spain (Sánchez Reyes et al. 2009) and other Mediterranean countries (Pyrri and Kapsanaki Gotsi 2017). Antón et al. 2019 reported that in the atmospheric air in Salamanca (Spain), Alternaria fungi evenly distributed throughout the year except for the summer, when they reached maximum concentrations in June and July. Concentrations of Aspergillus/Penicilium were generally low except for May. Corden et al. (2003) stated that high concentrations of Alternaria in the June-August period were associated with harvest time. Pyrri and Kapsanaki Gotsi (2015) did not observe a clear seasonal pattern for Aspergillus/Penicilium spores, but rather two overlapping patterns: while concentrations of Aspergillus increased in summer, concentrations of Penicillium decreased.

\subsection{Concentrations of mannitol-positive staphylococci and their identification}

Among airborne bacteria, staphylococci seem to be particularly important. They are commonly found in microbial flora of the skin and mucous membranes (Wolny-Koladka et al. 2019). Removed from these 
surfaces with dead skin cells (usually as a result of moving or scratching), they can drift in the air for several days. Potentially dangerous, they pose a particular threat to people with weakened or impaired immune system (Wolny-Koladka et al. 2019). The air at the investigated sports facilities contained only small concentrations of mannitol-positive staphylococci, i.e. 0-20 CFU m ${ }^{-3}$ (1-9 CFU m $\mathrm{m}^{-3}$ on average) (Table 4). The highest was typically recorded at sampling site IV (martial arts room), while the lowest, at sampling site V (swimming pool) and outside the building at sampling site VI (sports field). Similar observations have been made by other researchers, e.g. Wolny-Koladka et al. (2019) recorded the lowest Staphylococcus concentration in the outdoor air. Zhou and Wang (2013) reported that the air in a crowded, closed environment of a subway station contained a higher concentration of drug-resistant staphylococci than those in the outdoor air.

Eight Staphylococcus species were identified in the airborne microflora at the studied sports facilities, with the highest percentage of $S$. warneri and $S$. haemoliticus (17\% each), followed by S. epidermidis, S. capitis, S. sciuri and S. xylosus (13\% each) (Table 5). This species composition is similar to that identified in the air of the University of Agriculture in Kraków, where Wolny-Koladka et al. (2019) determined three dominant species, i.e., S. xylosus (18\%), S. sciuri (17\%), S. hominis (15\%). However, a different composition was determined by Giwa and Ogunjobi (2017) in the airborne microflora of the libraries of the University of Ibadan in Nigeria. They identified $S$. aureus, $S$. arlattae, S. chonia, S. haemolyticus and S. muscae.

Staphylococcus spp. is considered to be air quality indicators; they indicate the possible presence of pathogenic drug-resistant microorganisms, associated with a serious public health concern. Therefore, a need to monitor air quality in public facilities should be
Table 5 Species diversity of the genus Staphylococcus

\begin{tabular}{lll}
\hline Genus & Dominant species & Percentage (\%) \\
\hline Staphylococcus & S. warneri & 17 \\
& S. haemolyticus & 17 \\
S. epidermidis & 13 \\
S. capitis & 13 \\
S. sciuri & 13 \\
S. xylosus & 13 \\
S. auricularis & 6 \\
S. simulans & 6 \\
\hline
\end{tabular}

treated with due seriousness. Moreover, the World Health Organization (WHO) (2014) predicts the arrival of the so-called 'post-antibiotic' era. The organization emphasizes a relationship between the rate of acquiring antibiotic resistance by microorganisms, increased demand for new drugs, and the possibility of obtaining new antibacterial agents.

\subsection{Antimicrobial resistance of staphylococci}

Antibiotic resistance is caused (and accelerated) by the overuse and misuse of medicines, frequently as a result of misdiagnosis or inaccurate medical treatment. Once the strains acquire drug resistance, they are insensitive even to modern medications (Nahaei et al. 2015).

In our study, we identified both antibiotic-resistant and antibiotic-susceptible mannitol-positive Staphylococci. The isolates exhibited the highest rate of resistance to penicillin ( $73 \%$ of all strains) (Fig. 2), the fact which is associated with their ability to produce penicillinase. The results obtained by Gandara et al. (2006) suggested that a large percentage of Staphylococcus aureus strains isolated from residential homes
Table 4 Number of mannitol-positive staphylococci in air $\left(\mathrm{CFU} \mathrm{m} \mathrm{m}^{-3}\right.$ )

$M$ mean, $S D$ standard deviation

\begin{tabular}{lllllll}
\hline Sampling sites & \multicolumn{3}{l}{ Month of sampling } & $M \pm$ SD \\
\cline { 2 - 6 } & May & June & September & October & November \\
\hline I-gym & 0 & 2 & 8 & 6 & 0 & $3 \pm 4$ \\
II-fitness room & 0 & 2 & 8 & 2 & 4 & $3 \pm 3$ \\
III-sports hall & 0 & 4 & 10 & 2 & 10 & $5 \pm 5$ \\
IV-martial arts room & 3 & 2 & 18 & 4 & 20 & $9 \pm 9$ \\
V-swimming pool & 0 & 0 & 0 & 0 & 4 & $1 \pm 2$ \\
VI-sports field & 0 & 0 & 0 & 4 & 0 & $1 \pm 2$ \\
\hline
\end{tabular}


Fig. 2 Antimicrobial resistance of mannitolpositive staphylococci isolated from the air of the investigated sports facilities. P1-benzylpenicillin, TE30 - tetracycline, CN10-gentamicin, FOXcefoxitin, E15erythromycin, RA5rifampicin, LEV5levofloxacin

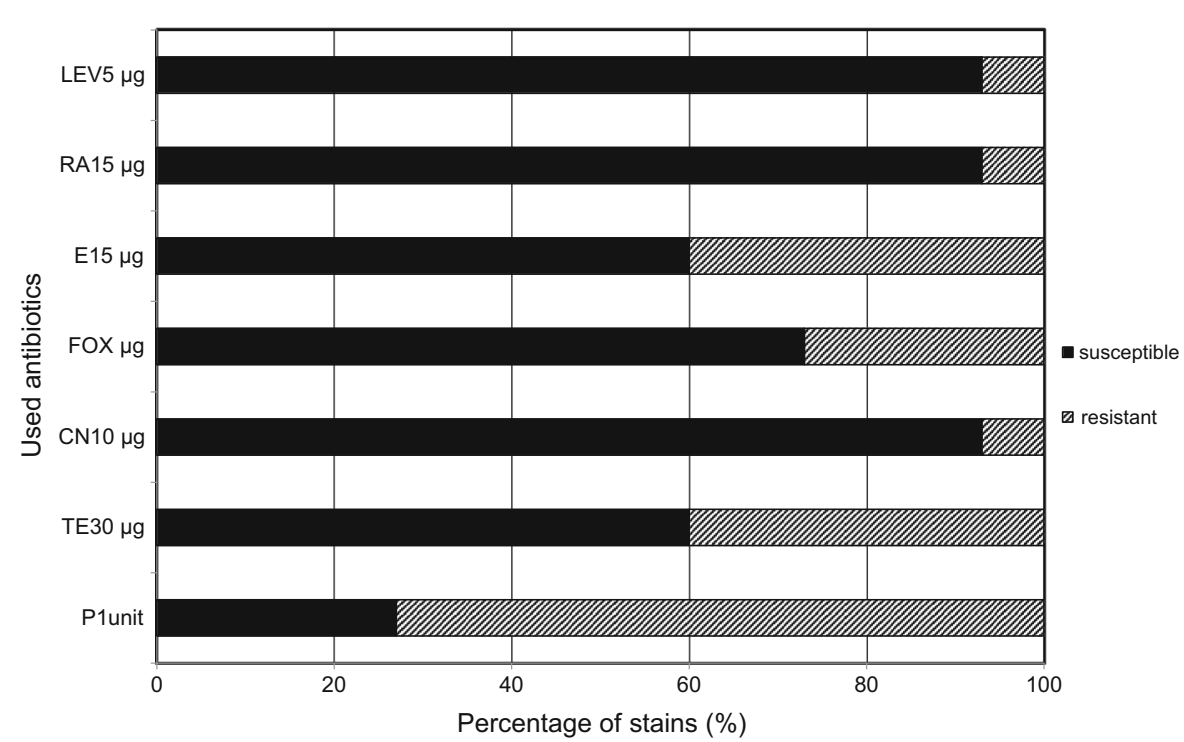

in Texas (USA) were also penicillin resistant. Similarly, Sivri et al. (2016) observed that coagulasenegative strains of staphylococci isolated from outdoor environments of the European side of Istanbul exhibited the highest resistance to penicillin, doxycycline and tetracycline. Our results indicated high resistance of these strains to tetracycline and erythromycin $(40 \%)$. The results obtained by WolnyKoladka et al. (2019) indicated that over $50 \%$ of staphyloccoci isolated from the indoor air of the Agricultural University in Kraców were resistant to erythromycin, and about 33\%, to tetracycline. According to Hrynkiewicz et al. (2005) strains isolated from environments other than hospitals showed sensitivity to the majority of known antibiotics, being resistant only to methacyclin and tetracycline. In the examined sports facilities in Bydgoszcz, we did not observe the spread of multidrug-resistant staphylococci; over $90 \%$ of the isolated strains were sensitive to gentamycin, levofloxacin, and rifampicin (Fig. 2).

In view of the fact that exercising constitutes an important element of a daily routine of people with sedentary jobs in well-developed countries, the air quality in indoor spaces used for practising sports should be routinely monitored (Žitnik et al. 2016). Regular exercise may provide numerous benefits for the body and mind, but poor air quality in sports facilities may put health of the users at risk (Sezakova et al. 2018). The impact of air contamination on human health should never be underestimated, even at low contaminant concentrations (Kim et al. 2015). Studies that examined the association between air quality and health demonstrated the negative effects of pollution (Andrade and Dominski 2018). In addition to regular monitoring of air quality in sports facilities, increasing awareness of microbial risk due to exposure to polluted air is also recommended.

\section{Conclusions}

Active leisure has many benefits and improves both physical and mental fitness. The promotion of healthy lifestyle has resulted in an increased use of sports facilities, such as gyms, swimming pools, fitness rooms, sports halls, and sports fields. Since air quality in these places affects health and performance of the users, its regular monitoring is extremely important. Air quality inside sports facilities should be examined to evaluate the capacity of pathogenic bacteria to acquire resistance to antibiotics and to avoid epidemiological risk.

Our study indicated higher emission of airborne heterotrophic bacteria in the indoor facilities. At the same time the concentration of fungi was higher in the outdoor air (sports field). The presence and movement of a large number of people had a significant impact on microbial contamination of indoor air. Multidrugresistant staphylococci were not identified in the investigated facilities. 
Funding This work was partially funded by the Polish Ministry of Science and Higher Education under the subsidy for statutory activity and under the program "Regional Initiative of Excellence" in 2019-2022 (Grant No. 008/RID/2018/19).

\section{Compliance with ethical standards}

Conflict of interest The authors declare that they have no conflict of interest.

Open Access This article is distributed under the terms of the Creative Commons Attribution 4.0 International License (http:// creativecommons.org/licenses/by/4.0/), which permits unrestricted use, distribution, and reproduction in any medium, provided you give appropriate credit to the original author(s) and the source, provide a link to the Creative Commons license, and indicate if changes were made.

\section{References}

Adams, R. I., Miletto, M., Taylor, J. W., \& Bruns, T. D. (2013). Dispersal in microbes: Fungi in indoor air are dominated by outdoor air and show dispersal limitation at short distances. The ISME Journal, 7, 1262-1273. https://doi.org/10.1038/ ismej.2013.28.

Almaguer, M., Aira, M. J., Rodríguez Rajo, F. J., Fernández González, M., \& Rojas Flores, T. I. (2015). Thirty-four identifiable airborne fungal spores in Havana, Cuba. Annals of Agricultural and Environmental Medicine, 2, 215-220. https://doi.org/10.5604/12321966.1152068.

Andrade, A., \& Dominski, F. H. (2018). Indoor air quality of environments used for physical exercise and sports practice: Systematic review. Journal Environmental Management, 206, 577-586. https://doi.org/10.1016/j.jenvman. 2017.11.001.

Andrade, A., Dominski, F. H., \& Coimbra, D. R. (2017). Scientific production on indoor air quality of environments used for physical exercise and sports practice: Bibliometric analysis. Journal Environmental Management, 196, 188-200. https://doi.org/10.1016/j.jenvman.2017.03.001.

Antón, S. F., de la Cruz, D. R., Sánchez, J. S., \& Reyes, E. S. (2019). Analysis of the airborne fungal spores present in the atmosphere of Salamanca (MW Spain): A preliminary survey. Aerobiologia. https://doi.org/10.1007/s10453-01909569-z.

Bardei, F., Bouziane, H., Trigo, M. M., Ajouray, N., Haskouri, F. L., \& Kadiri, M. (2017). Atmospheric concentrations and intradiurnal pattern of Alternaria and Cladosporium conidia in Tétouan (NW of Morocco). Aerobiologia, 33, 221-228. https://doi.org/10.1007/s10453-016-9465-z.

Bowers, R. M., McCubbin, I. B., Hallar, A. G., \& Fierer, N. (2012). Seasonal variability in airborne bacterial communities at a high-elevation site. Atmospheric Environment, 50, 41-49. https://doi.org/10.1016/j.atmosenv.2012.01. 005 .

Brągoszewska, E., Bedroń, I., Kozielska, B., \& Pastuszka, J. S. (2018). Microbiological indoor air quality in an office building in Gliwice, Poland: Analysis of the case study. Air
Quality, Atmosphere and Health, 11, 729-740. https://doi. org/10.1007/s11869-018-0579-z.

Brągoszewska, E., Mainka, A., \& Pastuszka, J. S. (2016). Bacterial aerosols in an urban nursery school in Gliwice, Poland: A case study. Aerobiologia, 32, 469-480. https:// doi.org/10.1007/s10453-015-9419-x.

Braniš, M., Šafránek, J., \& Hytychová, A. (2009). Exposure of children to airborne particulate matter of different size fractions during indoor physical education at school. Building and Environment, 44, 1246-1252. https://doi.org/ 10.1016/j.buildenv.2008.09.010.

Cabral, J. P. S. (2010). Can we use indoor fungi as bioindicators of indoor air quality? Historical perspectives and open questions. Science of the Total Environment, 408, 4285-4295. https://doi.org/10.1016/j.scitotenv.2010.07. 005.

Chmiel, M. J., Frączek, K., \& Grzyb, J. (2015). Problemy monitoring zanieczyszczeń mikrobiologicznych powietrza (the problems of monitoring microbiological air contamination). Woda-Środowisko-Obszary Wiejskie (Water-Environment-Rural Areas), 15(1), 17-27.

Corden, J. M., Millington, W. M., \& Mullins, J. (2003). Longterm trends and regional variation in the aeroallergen $\mathrm{Al}$ ternaria in Cardiff and Derby UK- are differences in climate and cereal production having an effect? Aerobiologia, 19, 191-199. https://doi.org/10.1023/B:AERO. $0000006529.51252 .2 \mathrm{f}$.

Crameri, R., Garbani, M., Rhyner, C., \& Huitema, C. (2014). Fungi: The neglected allergenic sources. Allergy, 69, 176-185. https://doi.org/10.1111/all.12325.

Das, S., \& Gupta-Bhattacharya, S. (2012). Monitoring and assessment of airborne fungi in Kolkata, India, by viable and non-viable air sampling methods. Environmental Monitoring and Assessment, 184, 4671-4684. https://doi. org/10.1007/s10661-011-2294-1.

Du, P., Du, R., Ren, W., Lu, Z., Zhang, Y., \& Fu, P. (2018). Variations of bacteria and fungi in PM2.5 in Beijing, China. Atmospheric Environment, 172, 55-64. https://doi. org/10.4209/aaqr.2017.07.0238.

Ejdys, E. (2009). Wpływ powietrza atmosferycznego na jakość bioaerozolu pomieszczeń szkolnych w okresie wiosennym i jesiennym - ocean mikologiczna. (Influence of the atmospheric air on the quality of bioaerosol in school rooms in spring and autumn-mycological evaluation). Ochrona Środowiska i Zasobów Naturalnych, 41, 142-150.

Elbert, W., Taylor, P. E., Andreae, M. O., \& Pöschl, U. (2007). Contribution of fungi to primary biogenic aerosols in the atmosphere: Wet and dry discharged spores, carbohydrates, and inorganic ions. Atmospheric Chemistry and Physics, 7, 4569-4588. https://doi.org/10.5194/acp-74569-2007.

EUCAST. (2015). European Committee on antimicrobial susceptibility testing. Breakpoints tables for interpretation of MICs and zones diameters. Version 5.0.

Feller, W. (1950). An introduction to the probability theory and its application. New York: Wiley.

Frankel, M., Bekö, G., Timm, M., Gustavsen, S., Hansen, E. W., \& Madsen, A. M. (2012). Seasonal variations of indoor microbial exposures and their relation to temperature, relative humidity, and air exchange rate. Applied and 
Environmental Microbiology, 78, 8289-8297. https://doi. org/10.1128/AEM.02069-12.

Gandara, A., Mota, L. C., Flores, C., Perez, H. R., Green, C. F., $\&$ Gibbs, S. G. (2006). Isolation of Staphylococcus aureus and antibiotic-resistant Staphylococcus aureus from residential indoor bioaerosols. Environmental Health Perspectives, 114, 1859-1864. https://doi.org/10.1289/ehp. 9585.

Garrett, M. H., Rayment, P. R., Hooper, M. A., Adramson, M. J., \& Hooper, B. M. (1998). Indoor airborne funfal spores, house dampness and associations with environmental factors and respiratory health in children. Clinical and Experimental Allergy, 28, 459-467.

Giwa, H. J., \& Ogunjobi, A. A. (2017). Prevalence of multiple antibiotic resistant bacteria in selected libraries of University of Ibadan, Nigeria. Journal American Science, 13, 18-25. https://doi.org/10.7537/marsjas130217.03.

Goung, S. N., Yang, J., Kim, Y. S., \& Lee, C. M. (2015). A pilot study of indoor air quality in screen golf courses. Environmental Science and Pollution Research, 22, 7176-7182. https://doi.org/10.1007/s11356-014-3947-8.

Grajewski, J., \& Twarużek, M. (2004). Zdrowotne aspekty oddziaływania grzybów pleśniowych i mikotoksyn. (Health aspects of mold and mycotoxin interactions). Alergia, 3, 45-49.

Grinn-Gofroń, A. (2011). Airborne Aspergillus and Penicillium in the atmosphere of Szczecin (Poland) (2004-2009). Aerobiologia, 27, 67-76. https://doi.org/10.1007/s10453010-9177-8.

Hrynkiewicz, W., Sulikowska, A., Szczypa, K., Gniadowski, M., \& Skoczyńska, A. (2005). Rekomendacje doboru testów do oznaczania wrażliwości bakterii na antybiotyki i chemioterapeutyki. (Recommendations for microbial sensitivity tests used to determine bacterial susceptibility to antibiotics and chemotherapeutics). Postepy Mikrobiologii, 44, 175-192.

Hyvärinen, A., Vahteristo, M., Meklin, T., Jantunen, M., Nevalainen, A., \& Moschandreas, D. (2001). Temporal and spatial variation of fungal concentrations in indoor air. Aerosol Science and Technology, 35, 688-695. https://doi. org/10.1080/02786820117763.

Jahnz-Rożyk, K. (2008). Wprowadzenie do alergii na antygeny grzybów pleśniowych. (Introduction to allergies to fungal antigens). Polski Merkuriusz Lekarski, 24, 1-7.

Kallawicha, K., Chao, H. J., \& Kotchasatan, N. (2019). Bioaerosol levels and the indoor air quality of laboratories in Bangkok metropolis. Aerobiologia, 35, 1-14. https://doi. org/10.1007/s10453-018-9535-5.

Khan, M., Perveen, A., \& Qaiser, M. (2016). Seasonal and diurnal variation of atmospheric fungal spore concentrations in Hyderabad, Tandojam-Sindh and the effects of climatic conditions. Pakistan Journal of Botany, 48, 1657-1663.

Kim, K. H., Kabir, E., \& Kabir, S. (2015). A review on the human health impact of air borne particulate matter. Environment International, 74, 136-143. https://doi.org/10. 1016/j.envint.2014.10.005.

Kuna, P. (2002). Astma oskrzelowa - epidemiologia, patofizjologia, klinika. (Asthma-epidemiology, pathophysiology, clinical studiem). Przewodnik Lekarza, 5, 22-31.
Kunzli, N. (2002). The public health relevance of air pollution abatement. The European Respiratory Journal, 20, 198-209. https://doi.org/10.1183/09031936.02.00401502.

Lacey, J. (1996). Spore dispersal-its role in ecology and disease: The British contribution to fungal aerobiology. Mycological Research, 100, 641-660. https://doi.org/10.1016/ S0953-7562(96)80194-8.

Lu, Z., Lu, W. Z., Zhang, J. L., \& Sun, D. (2009). Microorganisms and particles in AHU systems: Measurement and analysis. Building and Environment, 44, 694-698. https:// doi.org/10.1016/j.buildenv.2008.05.014.

Madureira, J., Aguiar, L., Pereira, C., Mendes, A., Querido, M. M., Neves, P., et al. (2018). Indoor exposure to bioaerosol particles: Levels and implications for inhalation dose rates in schoolchildren. Air Quality, Atmosphere and Health, 11, 955-964. https://doi.org/10.1007/s11869-018-0599-8.

Madureira, J., Paciência, I., Pereira, C., Teixeira, J. P., \& Fernandes, Ed O. (2015). Indoor air quality in Portuguese schools: Levels and sources of pollutants. Indoor Air, 26, 526-537. https://doi.org/10.1111/ina.12237.

Maya-Manzano, J. M., Muñoz-Triviño, M., Fernández-Rodríguez, S., Silva Palacios, I., Gonzalo Garijo, A., \& Tormo Molina, R. (2016). Airborne Alternaria conidia in Mediterranean rural environments in SW of Iberian Peninsula and weather parameters that influence their seasonality in relation to climate change. Aerobiologia, 32, 95-108. https://doi.org/10.1007/s10453-016-9424-8.

Meadow, J. F., Altrichter, A. E., Kembel, S. W., Kline, J., Mhuireach, G., Moriyama, M., et al. (2014). Indoor airbone bacterial communities are influenced by ventilation, occupancy, and outdoor air source. Indoor Air, 24, 41-48. https://doi.org/10.1111/ina.12047.

Millington, W., \& Corden, J. (2005). Long terms trends in outdoor Aspergillus/Penicillium spore concentration in Derby, UK from 1970 to 2003 and a comparative study in 1994 and 1996 with indoor air of two local houses. Aerobiologia, 21, 105-113. https://doi.org/10.1007/s10453005-4180-1.

Nabrdalik, M., \& Latała, A. (2003). Występowanie grzybów strzępkowych w obiektach budowlanych. (Mould in buldings). Roczniki PZH, 54, 119-128.

Nahaei, M. R., Shahmohammadi, M. R., Ebrahimi, S., \& Milani, M. (2015). Detection of methicillin-resistant coagulase negative Staphylococci and surveillance of antibacterial resistance in a multi-center study from Iran. Jundishapur Journal of Microbiology, 8, 19945. https://doi.org/10. 5812/jjm.19945v2.

Oliveira, M., Ribeiro, H., Delgado, J. L., \& Abreu, I. (2009). Seasonal and intradiurnal variation of allergenic fungal spores in urban and rural areas of the North of Portugal. Aerobiologia, 25, 85-98. https://doi.org/10.1007/s10453009-9112-z.

Onchang, R., \& Panyakapo, M. (2014). The physical environments and microbiological contamination in three different fitness centres and the participants' expectations: Measurement and analysis. Indoor and Built Environment, 25, 213-228. https://doi.org/10.1177/1420326X14543209.

Platts-Mills, T. A., Hayden, M. L., Chapman, M. D., \& Wilkins, S. R. (1987). Seasonal variation in dust mite and grasspollen allergens in dust from the houses of patients with 
asthma. Journal of Allergy and Clinical Immunology, 79, 781-791.

Pusz, W., Kita, W., \& Weber, R. (2014). Microhabitant influences the occurrence of airbone fungi in a copper mine in Poland. Journal of Cave and Karst Studies, 76, 14-19. https://doi.org/10.4311/2013mb0101.

Pyrri, I., \& Kapsanaki Gotsi, E. (2015). Evaluation of the fungal aerosol in Athens, Greece, based on spore analysis. Aerobiologia, 31, 179-190. https://doi.org/10.1007/s10453014-9355-1.

Pyrri, I., \& Kapsanaki Gotsi, E. (2017). Functional relations of airborne fungi to meteorological and pollution factor in a Mediterranean urban environment. Fungal Ecology, 30, 48-54. https://doi.org/10.1016/j.funeco.2017.08.007.

Ramos, C. A., Reis, J. F., Almedia, T., Alves, F., Wolterbeek, H. T., \& Almeida, S. M. (2015a). Estimating the inhaled does of pollutants during indoor physical activity. Science of the Total Environment, 527-528, 111-118. https://doi.org/10. 1016/j.scitotenv.2015.04.120.

Ramos, C. A., Viegas, C., Verde, S. C., Wolterbeek, H. T., \& Almeida, S. M. (2015b). Characterizing the fungal and bacterial microflora and concentrations in fitness centers. Indoor and Built Environment, 25, 872-882. https://doi. org/10.1177/1420326X15587954.

Ramos, C. A., Wolterbeek, H. T., \& Almeida, S. M. (2014). Exposure to indoor air pollutants during physical activity in fitness centers. Building and Environment, 82, 349-360. https://doi.org/10.1016/j.buildenv.2014.08.026.

Revel, G. M., \& Arnesano, M. (2014). Perception of the thermal environment in sports facilities through subjective approach. Building and Environment, 77, 12-19. https:// doi.org/10.1016/j.buildenv.2014.03.017.

Rocha, C. A., Sousa, F. W., Zanella, M. E., Oliveira, A. G., Nascimento, R. F., Souza, O. V., et al. (2017). Environmental quality assessment in areas used for physical activity and recreation in a city affected by intense urban expansion (Fortaleza-CE, Brazil): Implications for public health policy. Expo Health, 9, 169-182. https://doi.org/10. 1007/s12403-016-0230-x.

Sadyś, M. (2017). Effect of wind speed and direction on monthly fluctuations of Cladosporium conidia concentration in the air. Aerobiologia, 33, 445-456. https://doi.org/10.1007/ s10453-017-9482-6.

Samson, R. A., Hoekstra, E. S., Frisvad, J. C., \& Filtenborg, O. (2000). Introduction to food-and airborne fungi (6th ed.). Utrecht: Centraalbureau voor Schimmelcultures.

Sánchez Reyes, E., Rodríguez de la Cruz, D., Sanchís Merino, M. E., \& Sánchez, J. (2009). Meteorological and agricultural effects on airborne Alternaria and Cladosporium spores and clinical aspects in Valladolid (Spain). Annals of Agricultural and Environmental Medicine, 16, 53-61.

Sezakova, K., Peixoto, C., Oliveira, M., Delerue-Matos, C., Pereira, M. C., \& Morais, S. (2018). Indoor particulate pollution in fitness centres with emphasis on ultrafine particles. Environmental Pollution, 233, 180-193. https:// doi.org/10.1016/j.envpol.2017.10.050.

Sivri, N., Bağcigil, A. F., Metiner, K., Şeker, D. Z., Orak, S., Durak, S. G., et al. (2016). Curturable airbone bacteria and isolation of methicillin-resistant coagulase-negative staphylococci from outdoor environments on European side of Istanbul, Turkey. Archives of Environmental Protection, 3, 77-86. https://doi.org/10.1515/aep-2016-0034.

Skjøth, C. A., Damialis, A., Belmonte, J., De Linares, C., Fernández-Rodríguez, S., Grinn-Gofroń, A., et al. (2016). Alternaria spores in the air across Europe: Abundance, seasonality and relationships with climate, meteorology and local environment. Aerobiologia, 32, 3-22. https://doi. org/10.1007/s10453-016-9426-6.

Vesper, S. J., Wymer, L. J., Meklin, T., Varma, M., Stott, R., Richardson, M., et al. (2005). Comparison of populations of mould species in homes in the UK and USA using mould-specific quantitative PCR. Letters in Applied Microbiology, 41, 367-373. https://doi.org/10.1111/j. 1472-765X.2005.01764.x.

Viegas, C., Alves, C., Carolino, E., Rosado, L., \& Santos, C. S. (2010). Prevalence of fungi in indoor air with reference to gymnasiums with swimming pools. Indoor and Built Environment, 19, 555-561. https://doi.org/10.1177/ $1420326 X 10380120$.

WHO - World Health Organization. (2014). Antimicrobial resistance global report on surveillance. Geneva: World Health Organizations.

WHO - World Health Organization. (2016). Physical activity strategy for the WHO European region 2016-2025 (p. 1). Copenhagen: WHO Regional Office for Europe.

Wolny-Koładka, K., Malinowski, M., Pieklik, A., \& Kurpaska, S. (2019). Microbiological air contamination in university premises and evaluation of drug resistance of staphylococci occurring in the form of a bioaerosol. Indoor and Built Environment, 28, 235-246. https://doi.org/10.1177/ $1420326 X 17748463$.

Womack, A. M., Bohannan, B. J. M., \& Green, J. L. (2010). Biodiversity and biogeography of the atmosphere. Philosophical Transactions of the Royal Society B Biological Sciences, 365, 3645-3653. https://doi.org/10.1098/rstb. 2010.0283.

Yao, M., \& Mainelis, G. (2007). Analysis of portale impactor performance for enumeration of viable bioaerosols. Journal of Occupational and Environmental Hygiene, 4, 514-524. https://doi.org/10.1080/15459620701407388.

Zhou, F., \& Wang, Y. (2013). Characteristics of antibiotic resistance of airborne Staphylococcus isolated from metro stations. International Journal of Environmental Research and Public Health, 10, 2412-2426. https://doi.org/10. 3390/ijerph10104667.

Žitnik, M., Bučar, K., Hiti, B., Barba, Ž., Rupnik, Z., Založnik, A., et al. (2016). Exercise-Include effects on a gym atmosphere. Indoor Air, 26, 468-477. https://doi.org/10. 1111/ina.12226. 